Escudero, Inmaculada; León, José A.; Morera, Yurena (2013). Are discourse comprehension and cognitive procešses influenced by the type of language (English and Spanish)? A cross-language study based on elaborative inferences generation. Revista de Investigación Educativa, 31 (1), 223-237.

http://dx.doi.org/10.6018/rie.31.1.139071

\title{
ARE DISCOURSE COMPREHENSION AND COGNITIVE PROCESSES INFLUENCED BY THETYPE OF LANGUAGE (ENGLISH AND SPANISH)? A CROSS-LANGUAGE STUDY BASED ON ELABORATIVE INFERENCES GENERATION
}

\author{
Inmaculada Escudero \\ (UNED) \\ José A. León \\ (Universidad Autónoma de Madrid) \\ Yurena Morera \\ (Universidad de la Laguna)
}

\section{ABSTRACT}

The aim of this study was to determine whether discourse comprehension processes, focusing on the type of inferences activated during reading, would be influenced by the language (English and Spanish) as supported by linguistic relativity theories. 20 U.S. and 20 Spanish undergraduates took part in this study using a think-aloud task. The results suggest that inference generation was not restricted by language differences. In contrast, these data support the idea that inference activation reflects a universal cognitive processes pattern.

Keywords: cross-languages, comprehension processes, inference generation, linguistic relativity theories, think-aloud task.

\section{Correspondencia:}

Inmaculada Escudero. e-mail: iescudero@psi.uned.es. Tel.: 349139894 65. Dpto. de Psicología Evolutiva y de la Educación. Facultad de Psicología. UNED. Juan del Rosal, 10. 28040-Madrid (Spain)

Acknowledgments: This research was partly supported by a faculty research grant from the Spanish Ministry of Science and Technology (PSI2009-13932). We thank Dr Augusto Buchweitz (CCBI, Carnegie Mellon University) for their helpful comments on an earlier draft of this article. 


\section{¿ESTÁN LOS PROCESOS COGNITIVOS IMPLICADOS EN LA COMPRENSIÓN DEL DISCURSO INFLUIDOS POR ELTIPO DE LENGUA (INGLÉS VS ESPAÑOL)? UN ESTUDIO TRANSLINGÜÍSTICO BASADO EN LA GENERACIÓN DE INFERENCIAS ELABORATIVAS}

\section{RESUMEN}

El objetivo de este trabajo es determinar si los procesos de comprensión del discurso, en especial los diversos tipos de inferencias que se activan durante la lectura, están o no influidos por la lengua materna (inglés vs. español), tal y como apuntan algunas teorías sobre el relativismo lingüístico. En este estudio, consistente en una tarea de pensamiento en voz alta, participaron 20 estudiantes universitarios norteamericanos y 20 españoles. Los resultados obtenidos sugieren que la activación de inferencias no está restringida a las diferencias idiomáticas. Por el contrario, los datos apoyan la idea de que la activación de inferencias refleja un patrón universal en los procesos cognitivos.

Palabras clave: estudios translingüísticos, procesos de comprensión, generación de inferencias, tarea de pensamiento en voz alta, teorías lingüísticas relativistas.

During the past two decades, there has been significant research on inference generation in reading. Inferences, conceived as "encoded (implicit) features of the meaning of a text" (McKoon \& Ratcliff, 1989, p. 335) have been considered as the core of comprehension processes (Schank, 1975). The most common assumption is to consider that inference generation is a complex and necessary activity in day-to-day comprehension processes. Given its complexity, inference generation has been explained from various theoretical viewpoints and analyzed by different methods and measures. The extent of the inference depends on a number of different factors. While some inference processes seem to be automatic and effortless others, by contrast, seem to be dependent on the goals, strategies, and contextual situations of the readers. These include the level of reading skill, language skill, previous knowledge, and reading purpose (Escudero \& León, 2007; Fincher-Kiefer, 1995; León \& Pérez, 2001; Narváez, van den Broek \& Barrón, 1999). Nevertheless, over the past 60 years other theoretical perspectives, such as linguistics and anthropology, have developed and argued the possible impact that a language has on cognition. The theories that posit some shaping or determining effect of language on thought are typically grouped under the term of linguistic relativity theories (see Gumperz \& Levinson 1996, for a review). From another perspective, psychologists who study the online effects of language on thought processes advocate that there is no scientific evidence that languages dramatically shape their speakers ways of thinking (e.g., Pinker, 1994). In this study we intended to determine whether inference generation, as a product of discourse comprehension, would be impacted by the influence of language, as advocated by linguistic relativity theories; or, by contrast, whether inference generation is a universal cognition process that works independently of the language, as an inherent feature of our mind. 


\section{HOW LANGUAGE MAY AFFECT COMPREHENSION PROCESSES AND COGNITION}

Languages differ from one to another in terms of how they describe the world. Does the language we speak influence the way we think? This question, out of favor for many years, is most commonly associated with Sapir (1921) and Whorf (1956). Whorf, for example, proposed that the categories and distinctions of each language enshrine a way of perceiving, analyzing, and acting in, the world. Insofar as languages differ, their speakers too should differ in how they perceive and act in objectively similar situations. The understanding that a language impacts the cognition of its speakers is an old and heated debate between different points of view, especially linguistics, psychology and anthropology (see Gumperz \& Levinson 1996; Lucy 1992, for overviews). The theories on these aspects are typically grouped under the umbrella term of linguistic relativity theories, or also as the Sapir-Whorf Hypothesis (SWH).

In recent years, linguistic relativity theories have been regaining the interest of researchers (see Gentner \& Goldin-Meadow, 2003, for a review). Recent investigations have mostly centered on perceptual arenas such as space, time and motion. For example, studies have focused on how different languages describe spatial relations. Results show important differences between English, Spanish, Finnish, and Dutch, among other languages (e.g., Bowerman, 1996; Clark, 2004; Levelt, 1989; Levinson, 1996). For example, Levelt (1989) comparing deictic terms across languages concludes that English and Dutch speakers perceive distance to ego differently than Spanish and Japanese speakers. But when English and Dutch speakers express distance information, they must represent that information in their messages in bipartite form, whereas Spanish and Japanese speakers must use a tripartite code (Levelt, 1989). Languages also differ from one another in their descriptions of time, as described by Boroditsky's (2001) and Scott's (1989) comparison of English and Mandarin languages; in their grammatical distinction between objects and substances (Lucy \& Gaskins, 2001); and languages also differ in how objects are grouped into grammatical categories. For example, recent studies carried out by Boroditsky, Schmidt \& Phillips (2003) suggest that the grammatical genders assigned to objects by a language do indeed influence people's mental representation of objects in Spanish and German speakers.

Languages also differ from one another in their description of motion. Different authors and an important collection of different data strongly suggest differences between the users of Satellite-framed languages (S-languages), such as Germanic languages (e.g., Dutch, English, German, Icelandic, Swedish, and Yiddish) and Verb-framed languages (V-languages), such as Romance languages (e.g., French, Spanish, Italian, and Portuguese). S- and V-languages speakers attend to the components of motion events in different ways while producing or interpreting linguistic communication about motion. For S-language speakers, manner is an inherent component of directed motion along a path, and the semantic space of manner is highly differentiated. For V-language speakers, manner is much less salient and attention is focused on changes of location and settings in which motion occurs. The determining linguistic factor seems to be the availability of a mainverb slot for manner verbs in S-languages, in contrast to a main-verb slot for path verbs in V-languages (e.g., Aske, 1989; Slobin, 1996, 1997; Slobin \& Hoiting, 1994). 
From another perspective, classic studies in anthropological linguistics suggest that there are also substantial differences in semantic categories in social arenas such as kinship (Danziger, 2001; Foley, 1997; Romney \& D’Andrade, 1964). There are direct studies of the cognitive effects of social semantics. Boroditsky and Schmidt (2000) found effects of linguistic gender on people's encodings of objects. For example, they taught Spanish-English and German-English bilinguals English names for objects (such as "Mary" for a table) and found that people retained the names better when the gender was consistent with the gender of the noun in their first language. In addition, bilinguals' English descriptions of the objects were consistent with the gender in their first language.

From a different perspective, cognitive psychologists and linguists agree that linguistic universal processes do exist, but report evidence to the contrary (e.g. Heider, 1972; Li and Gleitman, 2002; Malt, Sloman, Gennari, Shi \& Wang, 1999). Different languages such as English, Spanish, German, Japanese or Finnish draw on the same mental or neural substrate. As Bates, Devescovi \& Wulfeck (2001) point out, "they do not 'live' in different parts of the brain". However, these authors also argued that "they can differ in the way this mental/neural substrate is taxed or configured, making differential uses of the same basic mechanisms for perceptual processing, encoding and retrieval, working memory, and planning" (p. 371). The online effects of language on thought processes have been noted by psychologists, though not perceived as centrally important to the classical issues of language and cognition. For example, Pinker (1994) writes that "there is no scientific evidence that languages dramatically shape their speakers' ways of thinking" (p. 57). Other authors have not found any evidence that linguistic distinctions do influence non-linguistic similarity and memory for scenes (Li \& Gleitman, 2002; Munnich, Landau \& Dosher, 2001).

One of the reasons for such controversy is that research on linguistic relativity is incomplete without tending to the cognitive processes that are brought to bear, online, in the course of using language. For example, Slobin (2003) writes that the voluminous literature on linguistic relativity has concerned itself primarily with the search for influences of particular languages on nonlinguistic cognition, in situations in which language is not being used. This represents a long tradition in which anthropologists, psychologists, and linguists alike have sought to relate grammatical and semantic systems of a language to the worldview, epistemology, or culture of the community of speakers of a language. There is another problem related to the methods applied to analyze differences between languages: the diversity of approach within crosslinguistic research has given rise to diversity in methods, which could be affecting a better comparison between studies (see Berry, 2000; Berry, Poortinga, Segall \& Dasen, 1992; Escudero, 2004; Kim, Park \& Park, 2000, for a review). Basically, cross-linguistic studies can be divided into two perspectives. One of these perspectives treats language like a between-subject variable, so it applies the same experimental design in two or more languages to determine how the linguistic differences affect the performance of a task. The second perspective, in turn, treats languages like experiments in their nature, exploring particular properties of a certain language, with the objective to formulate questions that cannot be answered in another language.

Slobin (1987) hypothesizes, in his "thinking for speaking," that when constructing utterances in discourse, one fits ones' thoughts into available linguistic forms. 
Nevertheless, there are not very many previous cross-language pieces of research that help us determine if discourse differences produce varying inference patterns in the same context. Most of comparative studies come from the fields of Linguistics and Psycholinguistics, and most have not focused on cross-language aspects concerning text comprehension processes. Only few studies have attempted to analyze cultural differences in the context of telling stories (e.g., Chafe, 1980; Tannen, 1980, 1983, 1984, 1988) or recall (e.g. Mandler, Scribner, Cole \& De Forest, 1980). By contrast, we hypothesized "reading for understanding" - that is, the time in which linguistically codable dimensions must be accessed and heeded through inferences that are necessary for text comprehension, while he or she is thinking aloud. In our current work, we seek to test whether verbally describing the text strengthens language effect. We work with two languages, English and Spanish (S versus V- languages). In addition, we further explored if different types of written discourse also strengthen the language effect. In this view, we think that is possible to compare anticipatory and consequence effects related to cognitive processes such as inferences, comprehension and interpretation processes as a critical interface between language and cognition.

\section{A FUNCTIONAL FRAMEWORK FOR ANALYZE THE IMPACT OF LANGUAGE AND TYPE OF TEXT THROUGH INFERENCES}

Inferences express cognition in our mind through the language used by the reader. Inferences constitute an ideal tool for studying cognition and comprehension processes while subjects read a text and think aloud. To investigate the inference processes during reading, different pieces of research have applied different measures. While many studies have used speeded techniques in which one element is probed for activation during reading (see Haberlandt, 1994 or Singer, 1994 for a review), others chose verbal protocol methods such as question answering (e.g. Graesser, 1981; Graesser \& Clark, 1985; Long, Oppy \& Seely, 1997) and think-aloud tasks (e.g. Escudero, 2004; Trabasso \& Magliano, 1996; Trabasso \& Suh, 1993; Zwaan \& Brown, 1996). In think-aloud research, readers have demonstrated a variety of reactions during reading, including conscious inference-making, text integration, and text interpretation (see León \& Escudero, 2003 or Pressley \& Afflerbach, 1995 for a review). In particular, think-aloud has been used as a method that reveals inferences and mental processes that occur during comprehension. In addition, think-aloud tasks ought to show the information available in working memory and also information that is consciously used and encoded (Ericsson \& Simon, 1993).

Most constructionist frameworks adopt the idea that a finite set of inference categories could be produced during comprehension (e.g. Graesser, Singer \& Trabasso, 1994; van den Broek, Fletcher \& Risden, 1993). As far as stories are concerned, van den Broek et al. (1993) distinguished between backward, forward and concurrent inferences. Trabasso and Magliano (1996) adopted a similar approach and, in addition, categorized explanations as backward inferences, associations as being concurrent, and predictions as forward inferences, thus establishing important connections between time and the type of inference generated. The authors proposed three types of inferences that can be activated during the comprehension of a sentence: (1) explanation, (2) prediction, and (3) association. 
Explanatory, associative, and predictive inferences are functionally different. According to Trabasso and Magliano (1996), explanation and prediction each serve to integrate sentences across the text. Explanatory inferences are "backward" oriented in narrative time and serve the purpose of linking the focal sentence (the sentence being read) with either text information or prior knowledge-based inferences. Explanatory inferences often provide reasons as to why something occurs. The readers form expectations about the causal antecedents. Explanatory reasoning is the primary means by which coherence in understanding is achieved. In narrative discourse, an explanation could provide a basis, rationale, motive, idea, condition, pretext, or the "why and wherefore" of events, states and actions. But explanations are also assumed to be the main form of understanding in scientific and naive reasoning about physical reality (Chi, de Leeuw, Chiu \& LaVancher, 1994; León, 2009). In contrast, predictive inferences are oriented to the "future" and they are identified as expectations based on prior knowledge and the information contained in the focal sentence. Predictions, like explanations, are manifestations of causal cognition and comprehension processes. Lastly, associations can provide information about who does what to whom and with what, when, and where. Predictions also provide information on features, properties, relations, and functions of people, objects, or concepts (Trabasso \& Magliano, 1996). They are concurrent with the information in the focal sentence and they are usually based on the activation of the reader's relevant world knowledge rather than on the use of prior information in the text. In this study, we adopted the analysis framework proposed by these authors because we were particularly interested in the fact that more than $70 \%$ of readers' responses corresponded to these kinds of inferences.

\section{EXPERIMENT}

This study investigates reading processes assessed by verbal protocols in written discourse into two languages. More specifically, how elaborative inferences are used to construct the meaning of text written into Spanish and English languages. The research question addressed in this research is: do Spanish speakers use the same cognitive processes or differently from English speakers?

\section{METHOD}

Participants. Forty subjects took part in this study. Twenty were English speakers and at the time undergraduate students (first-year Psychology) at the University of Minnesota, U.S. The other twenty subjects were Spanish undergraduate students (firstyear Psychology) at the Autónoma University of Madrid. All participants received two academic credits for their participation.

Materials. Initially, 60 texts were taken from newspaper articles, novels, encyclopedias, handbooks, scientific journals, and stories used in previous experiments by other researchers. The texts included, at least, one causal relation. Two preliminary studies were done in order to select the experimental texts. Sixty subjects responded to a questionnaire. In the first preliminary study, subjects had to categorize each text 
(narrative, expository or argumentative) without being informed about their source, and had to evaluate their difficulty. The texts selected had at least $65 \%$ categorization agreement and the same level of difficulty. In the second preliminary study, we ran a reading time task to ensure that there were no significant differences between these types of texts.

A total of 20 texts were selected: 9 narratives, 4 argumentative texts (news) and 7 expository texts (encyclopedias and handbooks). The texts were presented to Spanish and U.S. students in their mother language. The original versions of texts were in English. The translations into Spanish were intended to reflect the same structure and style of the original texts. We took special care to avoid any cultural or national bias when compiling the texts, as this could alter the results of the task. All texts used had the same number of sentences (10) and the same sentence lengths.

Procedure. Participants were tested individually in a quiet lab room. A simple, no directive, think-aloud instruction was used following Trabasso \& Suh (1993) and Zwaan \& Brown (1996). The participants spoke into the microphone of a tape recorder. The texts were presented in random order so that each subject read 20 texts. All of the texts were presented on the computer screen one sentence at a time. This presentation format (sentence by sentence), and the fact that the students were not allowed going back to previous sentences basically follows the verbal protocol assessment criteria set out by Ericsson \& Simon (1993). Thus, it was possible to more accurately determine at which point in the text inferences were generated. Moreover, this format of presentation creates pauses between sentences, which the participants can use to verbalize information in working memory pertaining to the prior sentence. Subjects were first given a practice text with the aim of familiarizing them with the task. Once the practice stage had been completed, the students proceeded to work through the experimental texts.

Assessment and classification of verbal protocols. The think-aloud protocols were tape-recorded and transcribed in the language they were generated, and were segmented into clauses. Each group of clauses (Spanish and English) was evaluated by expert native speakers. These clauses constituted our unit of analysis. In total, the participants (40) collectively generated 2886 clauses, which were classified into 12 categories. After having expanded our categorization scheme, we conducted interrater reliability tests. Four experts separately analyzed a sample of approximately 200 clauses. Initial reliability was .87 (Cohen's Kappa). Disagreements were solved through consensus. Next, a second reliability test was performed on another sample of approximately 200 clauses. Interrater reliability was .94 (Cohen's Kappa) and disagreements were solved through consensus.

To analyze the protocols we used the categorization scheme developed by Trabasso \& Magliano (1996), Zwaan \& Brown (1996) and Narváez, van den Broek \& Barrón (1999). Thus, we found many categories in common in these previous studies. Trabasso \& Magliano proposed three kinds of inferences: explanations, associations and predictions. Zwaan \& Brown (1996) proposed evaluations, paraphrases, and metacomments, which are further developed into several subcategories (hedges, word problems, sentence problems, prediction substantiations, mater-of-fact statements, and 
analytical statements). Narváez and colleagues (1999), using a categorization scheme similar to Zwaan \& Brown (1996), established the following categories: associations, explanations, predictions, evaluations, text-based coherence breaks, knowledge-based coherence breaks, and repetitions.

Trying to integrate the previous criteria, we established two main groups: Statements considered inferences, which we called Inferences Statements, and Statements that implied other kind of information, such as exclamations, comprehension problems or repetitions. These statements compose the Other Statements group. The categories included in each group are as follows:

Inferences Statements. The answers corresponding to these categories are considered inferences. 1889 clauses out of the total 2886 clauses (65.5\% of the total) were categorized as inferences in our study. This result is in consonance with other studies (e.g., Trabasso and Magliano, 1996). Although some of these categories have already been discussed in the theoretical review, new categories will be also examined (cohort effect, forward expectations and confirmation of predictions). We will now make a brief definition of each category.

- Associations: This category was defined by Trabasso and Magliano (1996). They are those concepts, ideas or examples that subjects activate during reading. They are often the result of the activation of previous knowledge. For example, while the subject read "A large transatlantic liner was sailing through the cold waters of Alaska" he said Um! It reminds me of the story of the Titanic. Their main purpose is to enhance the situational model, adding more detail, and the associations can refer to certain characteristics, aspects, connections and the role of different characters, objects or concepts that appear in the text.

- Explanations: They are inferences concerning causal antecedents (e.g. a cause, a reason, or a motive) for a certain event or action mentioned in the text (Trabasso \& Magliano, 1996). For instance, in the sentence "The pressure inside a sealed bottle of soda water", a reader said: Maybe just because the temperature is higher too. Their main purpose is to integrate different sentences of the text.

- Predictions: They are inferences about 'what will happen later' in the text. They can imply expectations concerning facts, aims, actions, results, or emotions (Trabasso \& Magliano, 1996). Thus, in the example "He was looking at it when the train suddenly braked" the reader said: The soup will spill over his legs.

- Cohort effect: This cohort concept was developed by van den Broek, Young, Tzeng \& Linderholm (1999). This is a kind of association inference but more complex (supra-association). This is a joint activation arising from one or several concepts in the text and from another series of associated concepts and/or a mental model associated with them. So, in the sentence "David took the Philadelphia flight to go to a meeting", the reader said: I imagine he is a businessman of a big company and has an important international meeting, where "businessman" or "company" could be considered here as a concept that prompts the activation of cohort concepts such as briefcase, stress, office, travel, money, and so on.

- Forward expectations: They involve the anticipation of a probable prediction but with a relatively low degree of specificity without producing a definition or 
without anticipating an action or a specific or concrete state. For example, in the sentence "Something unusual had been detected and they were waiting for the result of the tests", the reader said: Oh, maybe something wrong will happen. These categories are not complete predictions but they could be indicating an initial process to build a predictive inference. For this reason, this kind of inference is considered expectation, because the final construction is yet to be completed.

- Backward expectations or Confirmation of predictions: They are predictions made from a sentence that are later confirmed in the text. Their purpose is to integrate various sentences and to establish coherence in the text. Thus, they are also defined as backward expectations, since they refer to information which has already been presented. In the sentence "While passengers were asleep, the ship suddenly hit an iceberg" a reader told us: That's exactly what I said would happen. As the previous case, this category could be confirming that a predictive inference was constructed during reading and that this inference was not detected by the think-aloud task. Categories like this could indicate that the readers generate more inferences or more mental activity than is possible to observe with this methodology. This category is similar to the defined one by Zwaan \& Brown (1996) and that receives the name of "predictions substantiations".

Other Statements. A substantial portion of the clauses (997, 34.5\% of the total) did not fit into any of the inference categories described above. This category involves statements corresponding to metacomments as defined by Zwaan \& Brown (1996). We divided them into six groups:

- Comprehension problems: They are statements about the difficulty to comprehend part of the text, perhaps a word, a sentence or a group of sentences. This could be due to the nature of the text itself or to the absence of previous knowledge. For example, there is a comprehension problem when a subject read the sentence "Nitrogen-fixing bacteria enrich the soil by producing nitrates to green plants" and answered: I don't understand what it means. Indeed, I don't know what is a nitrogen-fixing bacteria...I've never hard before. In other studies this category has been divided into two subcategories: text-based coherence break and knowledgebased coherence break (e.g. Narváez et al., 1999), or also into word problems and hedges (e.g. Zwaan \& Brown, 1996).

- Paraphrasing: This is putting a sentence or an idea in other words while retaining the original meaning and a part of structure of the original sentence. In the text sentence "The leaf fell into the water" a reader answered: So, there is a leaf into the water.

- Repetition: This is the literal repetition of words or sentences appearing in the text and which therefore involves the reproduction of a part of the structure.

- Exclamations: As its own name indicates, they are exclamations activated by the subject during reading.

- Empathy: This concerns the statements made by the reader showing his/her ability to put himself/herself in the place of the character in the text, to infer and experience the character's thoughts, feelings and attitudes, taking and judging them as if they were his/her own. In the example "When she saw what had 
happened, Jennifer got really upset", an answer pertaining to this category was I understand her...I use to spend a lot of time dressing when I have a party...It will annoy me in the end.

- Evaluations: They are observations made by the reader about the content of the text, the actions of the characters or the results or sequence of the various events. They also indicate the reader's emotional state or reaction to the context of the text. Thus, in the sentence "They had taken valium with bourbon at the party" the answer So, there, I don't understand why they killed him...I think it's not an excuse, could be considered as an evaluation.

Design. In order to analyze the verbal protocols produced by students during the think-aloud task, first we carried out a qualitative analysis ( $t$ student) to classify them into categories. These categories let us make future comparative analysis. Second, with the objective to analyze if these categories were or not different between languages we carried out a Manova 2 (group: U.S. and Spanish participants) x 12 (verbal protocol categories), being group a between-subjects variable and the type of texts and categories within-subjects variables. This data are expressed by means (weighted) per clause and text.

\section{RESULTS}

All statistical analyses were conducted with a mixed Anova 2 (Group) x 12 (Categories), being Group the between-subject variable and Categories the withinsubject variable. There were significant effect of Category variable $[(F(11,418)=190.36$, $\mathrm{p}<0,001, M S E=6.68)]$. There were no significant differences in the Group variable $[F(1,38)=.16, p=.901, M S E=13.31]$. Also there were no significant differences in Group $x$ Category interaction, $[F(11,418)=.929, p=.512, M S E=6.68]$.

\section{Analysis of verbal protocols categories}

The comparison of means between all categories shows that some categories were significantly higher or lower than others (see Table 1 for details and Figure 1). Grouping data regarding inference statements, Predictions were more significant frequent than the rest of inference statements $(\mathrm{p}<.001)$. Explanations were also more significantly frequent than the other inference statements ( $\mathrm{p}<.001)$, except Predictions. Associations and Forward expectations were significantly more frequent than Cohort $(\mathrm{p}<.001)$. Also, Confirmation of predictions was significantly more frequent than Cohort $(\mathrm{p}=.001)$. Regarding the other statements, Exclamations were significantly more frequent than Comprehension problems, Empathy, and Evaluations $(\mathrm{p}<.001)$, Repetitions $(\mathrm{p}=.001)$ and Paraphrases $(\mathrm{p}=.003)$. In conclusion, inferences statements were more frequent than the other statements. In fact, Predictions and Explanations represented almost half of the total statements. 


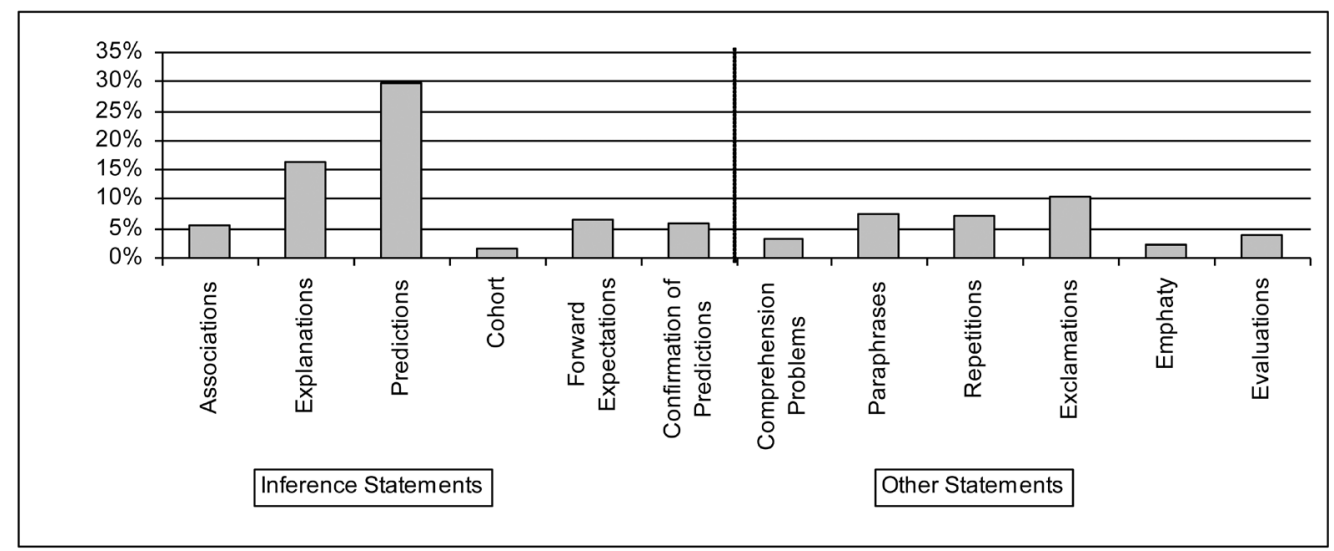

FIGURE 1

PROPORTIONS (\%) OF INFERENCE STATEMENTS AND OTHER STATEMENTS PER CLAUSE, SEGREGATED BY CATEGORIES

\section{Cross-language comparison of inference generation}

There were no significant differences in the Group variable. These data confirm the idea that language differences in relation to this variable do not affect inference generation. Thus a very similar pattern or behavior was obtained in the participants' answers.

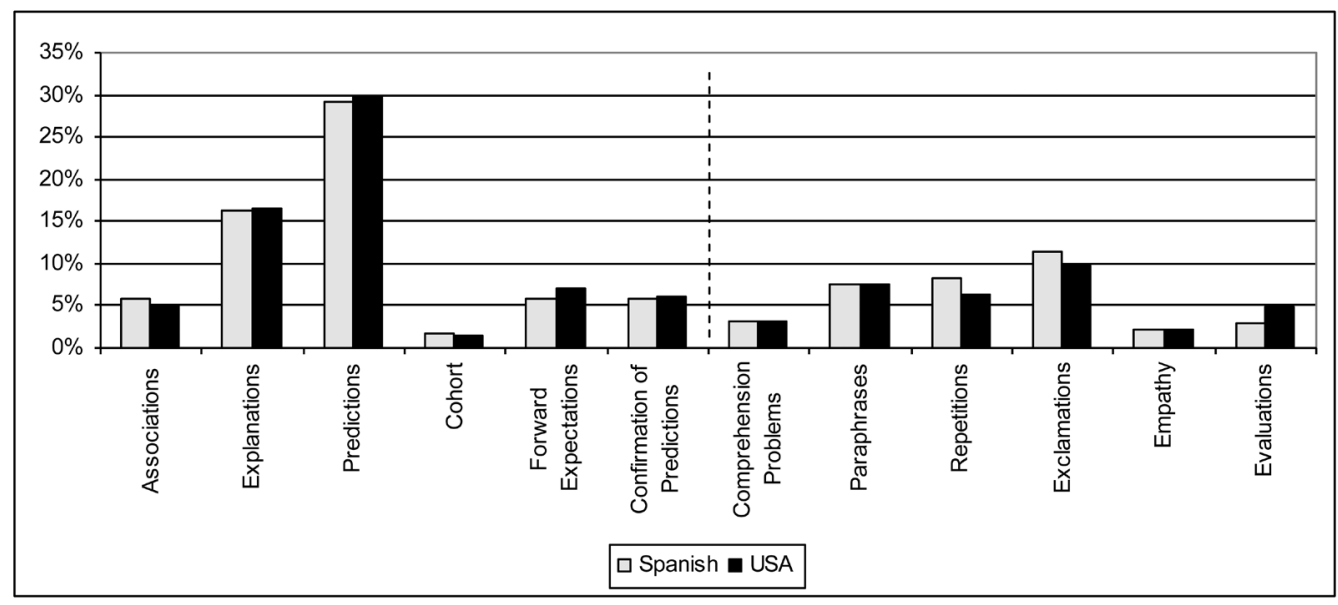

FIGURE 2

PROPORTIONS (\%) OF INFERENCE STATEMENTS AND OTHER STATEMENTS PER CLAUSE, SEGREGATED BY CATEGORIES AND GROUP 


\section{DISCUSSION}

In this study we characterize the importance of language for the properties of cognitive processes. However, we do not argue that thought and actions are entirely determined by language. In this sense, definitively providing answers to less deterministic versions of the 'does language shape thought' question has proven to be a necessary task. It is important to test whether these linguistic differences have cognitive consequences. We could postulate the existence of a universal criterion in inference generation, at least with respect to a think aloud task. Nevertheless, we must be careful drawing conclusions from this data, and render clear what is the universal characteristic of inferences. In spite of the clarity of the results, this study is not conclusive. But one of the positive results is the approach put forth in our study. As an indication for future studies, there is a need for a wider cross-language approach, to corroborate these results with other languages (e.g., Asian, Arab, etc.).

In the current study, we applied an analysis of language, language that is spoken (English and Spanish). The assessment seems not to influence comprehension processes, confirming the notion that of universal processes, at least in respect to English and Spanish and based on think aloud tasks. In language, comprehension is generally ahead of production. Still, researchers rarely investigate whether subjects really understand specific terms, or whether they are just making reasonable pragmatic inferences about what speakers probably mean. How can researchers examine these alternatives, and carefully document when readers understand the linguistic forms used? The use of "reading for understanding" in this study may provide an alternative link between research on language and thought, and that on comprehension processing through inference study. Thus, our findings provide evidence that the discourse structure can influence inference processing independently of the language used by the reader. Further enlightenment of questions like this would are essential for a better understanding of language and thought, and for opening an important path for future research.

\section{REFERENCES}

Aske, J. (1989). Path predicates in english and spanish: A closer look. Proceedings of the Fifteenth Annual Meeting of the Berkeley Linguistics Society, 1-14.

Bates, E., Devescovi, A., \& Wulfeck, B. (2001). Annual Review of Psychology, 52, 369-396. Berry, J.W. (2000). Cross-cultural psychology: A symbiosis of cultural and comparative approaches. Asian Journal of Social Psychology, 3, 197-205.

Berry, J. W., Poortinga, Y. H., Segall, M. H., \& Dasen, P. R. (1992). Cross-cultural psychology: Research and applications. Cambridge, MA: Cambridge University Press.

Boroditsky, L. (2001). Does language shape thought? Mandarin and english speakers' conceptions of time. Cognitive Psychology, 43, 1-22.

Boroditsky, L., Schmidt, L. A., \& Phillips, W. (2003). Sex, syntax and semantics. En D. Gentner \& S. Goldin-Meadow (Eds.), Language in mind: advances in the study of language and thought (pp. 61-78). Cambridge, MA: The MIT Press.

Bowerman, M. (1996). The origins of children's spatial semantic categories: cognitive versus linguistic determinants. En J. Gumperz \& S. Levinson (Eds.), Rethinking linguistic relativity (pp. 145-176). Cambridge, MA: Cambridge University Press. 
Chafe, W. L. (1980). The pear stories: Cognitive, cultural and linguistic aspects of narrative production. Norwood, NJ: Ablex Publishing Company.

Chi, M. T. H., Leeuw, N. de, Chiu, M. H., \& LaVancher, C. (1994). Eliciting selfexplanations improves understanding. Cognitive Science, 18, 439-477.

Clark, E. V. (2004). How language acquisition builds on cognitive development. Trends in Cognitive Sciences, 8, 472-478.

Danziger, E. (2001). Relatively speaking: Language, thought and kinship in Mopan Maya. Nueva York: Oxford University Press.

Ericsson, K. A., \& Simon, H. A. (1993). Protocol analysis: Verbal reports as data. Cambridge, MA: MIT Press.

Escudero, I. (2004). Procesamiento de inferencias elaborativas en la comprensión del discurso y según el tipo de texto (Tesis Doctoral no publicada). Universidad Autónoma de Madrid, España.

Escudero, I., \& León, J. A. (2007). Procesos inferenciales en la comprensión del discurso escrito. Influencia de la estructura del texto en los procesos de comprensión. Revista Signos, 40, 311-336.

Fincher-Kiefer, R. (1995). Relative inhibition following the encoding of bridging and predictive inferences. Journal of Experimental Psychology: Learning, Memory, and Cognition, 21, 981-995.

Foley, W. (1997). Anthropological linguistics: An introduction. Oxford: Blackwell Publishers.

Gentner, D., \& Goldin-Meadow, S. (2003). Language in mind: Advances in the study of language and thought. Cambridge, MA: MIT Press.

Graesser, A. C. (1981). Prose comprehension beyond the world. Nueva York: Springer-Verlag.

Graesser, A. C., \& Clark, L. F. (1985). Structures and procedures of implicit knowledge. Norwood, NJ: Ablex Publishing Company.

Graesser, A. C., Singer, M., \& Trabasso, T. (1994). Constructing inferences during narrative text comprehension. Psychological Review, 101, 371-395.

Gumperz, J., \& Levinson, S. (1996). Rethinking linguistic relativity. Cambridge, UK: Cambridge University Press.

Haberlandt, K. F. (1994). Methods in reading research. En M. A. Gernsbacher (Ed.), Handbook of psycholinguistics (pp.1-31). San Diego, CA: Academic Press.

Heider, E. R. (1972). Universals in color naming and memory. Journal of Experimental Psychology, 93, 10-20.

Kim, U., Park, Y. S., \& Park, D. (2000). The challenge of cross-cultural psychology: The role of the indigenous psychologies. Journal of Cross-Cultural Psychology, 31, 63-75.

León, J. A. (2009). Neuroimagen de los procesos de comprensión en la lectura y el lenguaje. Psicología Educativa, 15, 1, 61-71.

León, J. A., \& Escudero, I. (2003). Protocolos verbales en el estudio de las inferencias: Una metodología emergente. En J. A. León (Coord.), Conocimiento y discurso. Claves para inferir y comprender (pp. 100-119). Madrid: Pirámide.

León, J. A., \& Pérez, O. (2001). The influence of prior knowledge on the time course of clinical diagnosis inferences: A comparison of experts and novices. Discourse Processes, 31, 187-213.

Levelt, W. J. M. (1989). Speaking: From intention to articulation. Cambridge, MA: MIT Press. 
Levinson, S. (1996). Frames of reference and Molyneux's question: crosslinguistic evidence. En P. Bloom \& M. Peterson (Eds.), Language and space (pp. 109-169). Cambridge, MA: MIT Press.

Li, P., \& Gleitman, L. (2002). Turning the tables: Language and spatial reasoning. Cognition, 83, 265-294.

Long, D. L., Oppy, B. J., \& Seely, M. R. (1997). A “global-coherence" view of event comprehension: Inferential processing as question answering. En P.W. van den Broek, P. J. Bauer, \& T. Bourg (Eds.), Developmental spans in event comprehension and representation. Bridging fictional and actual events (pp. 361-384). Mahwah, NJ: Lawrence Erlbaum Associates.

Lucy, J. (1992). Grammatical categories and cognition: A case study of the linguistic relativity hypothesis. Cambridge, UK: Cambridge University Press.

Lucy, J., \& Gaskins, S. (2001). Grammatical categories and the development of classification preferences: a comparative approach. En M. Bowerman \& S. Levinson (Eds.), Language acquisition and conceptual development (pp. 257-283). Cambridge, UK: Cambridge University Press.

Malt, B., Sloman, S., Gennari, S., Shi, M., \& Wang, Y. (1999). Knowing versus naming: similarity and the linguistic categorization of artifacts. Journal of Memory and Language, 40, 230-262.

Mandler, J. M., Scribner, S., Cole, M., \& De Forest, M. (1980). Cross-cultural invariance in story recall. Child development, 51, 19-26.

McKoon, G., \& Ratcliff, R. (1989). Semantic associations and elaborative inference. Journal of Experimental Psychology: Learning, Memory, and Cognition, 15, 326-338.

Munnich, E., Landau, B., \& Anne Dosher, B. (2001). Spatial language and spatial representation: a cross-linguistic comparison. Cognition, 81, 171-208.

Narváez, D., van den Broek, P., \& Barrón-Ruiz, A. (1999). Reading purpose, type of text, and their influence on think-aloud and comprehension measures. Journal of Educational Psychology, 91, 488-496.

Pinker, S. (1994). The language instinct: How the mind creates language. Nueva York: Morrow.

Pressley, M., \& Afflerbach, P. (1995). Verbal protocols of reading: The nature of constructively responsive reading. Hillsdale, NJ: Lawrence Erlbaum Associates.

Romney, A. K., \& D'Andrade, R. G. (1964). Cognitive aspects of English kinship terms. American Anthropologist, 66, 146-270.

Sapir, E. (1921). Language. Nueva York: Harcout, Brace and World.

Schank, R. C. (1975). The structure of episodes in memory. En D. G. Bobrow \& A. M. Collins (Eds.), Representation and understanding: Studies in cognitive science. Nueva York: Academic Press.

Scott, A. (1989). The vertical dimension and time in Mandarin. Australian Journal of Linguistics, 9, 295-314.

Singer, M. (1994). Discourse inference processes. En M. A. Gernsbacher (Ed.), Handbook of psycholinguistics (pp. 479-515). San Diego, CA: Academic Press.

Slobin, D. I. (1987). Thinking for speaking. Proceedings of the Thirteenth Annual Meeting of the Berkeley Linguistics Society, 435-444. 
Slobin, D. I. (1996). Two ways to travel: Verbs of motion in English and Spanish. En M. Shibatani \& S. A. Thompson (Eds.), Grammatical constructions: Their form and meaning (pp. 195-217). Oxford: Oxford University Press.

Slobin, D. I. (1997). Mind, code, and text. En J. Bybee, J. Haiman, \& S. A. Thompson (Eds.), Essays on language function and language type: Dedicated to T. Givón (pp. 437467). Amsterdam: John Benjamins.

Slobin, D. I. (2003). Language and thought online: Cognitive consequences of linguistic relativity. En D. Gentner \& S. Goldin-Meadow (Eds.), Language in mind: Advances in the study of language and thought (pp. 157-192). Cambridge, MA: MIT Press.

Slobin, D. I., \& Hoiting, N. (1994). Reference to movement in spoken and signed languages: Typological considerations. Proceedings of the Twentieth Annual Meeting of the Berkeley Linguistics Society, 487-505.

Tannen, D. (1980). A comparative analysis of oral narrative strategies: Athenian Greek and American English. En W. L. Chafe (Ed.), The pear stories: Cognitive, cultural and linguistic aspects of narrative production. Norwood, NJ: Ablex Publishing Company.

Tannen, D. (1983). I take out the rok-dok!: How Greek women tell about being molested (and create involvement). Anthropological Linguistics, 359-374.

Tannen, D. (1984). Spoken and written narrative in english and greek. En D. Tannen (Ed.), Coherence in spoken and written discourse. Norwood, NJ: Ablex Publishing Company.

Tannen, D. (1988). Hearing voices in conversation, fiction and mixed genres. En D. Tannen (Ed.), Linguistics in contexts: Connecting observation and understanding. Norwood, NJ: Ablex Publishing Company.

Trabasso, T., \& Magliano, J. P. (1996). Conscious understanding during text comprehension. Discourse Processes, 21, 255-287.

Trabasso, T., \& Suh, S. (1993). Understanding text: Achieving explanatory coherence through on-line inferences and mental operations in working memory. Discourse Processes, 16, 3-34.

van den Broek, P., Fletcher, C. R., \& Risden, K. (1993). Investigations of inferential processes in reading: A theoretical and methodological integration. Discourse Processes, 16, 169-180.

van den Broek, P., Young, M., Tzeng, Y., \& Linderholm, T. (1999). The landscape model of reading: Inferences and the online construction of a memory representation. En H. van Oostendorp \& S. Goldman (Eds.), The construction of mental representations during reading (pp. 71-98). Mahwah, NJ: Lawrence Erlbaum Associates.

Whorf, B. (1956). Language, thought and reality: Selected writings of Benjamin Lee Whorf. Cambridge: MIT.

Zwaan, R. A., \& Brown, C. M. (1996). The influence of language proficiency and comprehension skill on situation-model construction. Discourse Processes, 21, 289-327.

Fecha de recepción: 3 de diciembre de 2011.

Fecha de revisión: 3 de diciembre de 2011.

Fecha de aceptación: 25 de marzo de 2012. 
